Проаналізувавши погляди К.Юнга на сутність та світоглядну природу релігії, можна зробити висновок, що він одним з перших в історії релігієзнавчої думки звернув увагу на несвідоме підгрунтя релігії, побачив психологічний сенс релігійних поглядів та уявлень людини.

Можна погоджуватися чи не погоджуватися 3 основними поглядами мислителя на природу релігії, проте його звернення до психологічних джерел релігії дозволяє побачити проблему ії визначення в дещо нестандартному аспекті, розширити спектр релігієзнавчого дискурсу.

\title{
С.Капранов* ${ }^{*}$ м. Київ) \\ РЕЛІГІЙНО-ФІЛОСОФСЬКА КУЛЬТУРА РАННЬОГО ХЕЙАНУ
}

Ранній Хейан $(794$ - 901) цікавий для релігієзнавців принаймні 3 двох причин. По-перше, в цей час у Японії виникає самостійна професійна філософія (буддистська за характером). По-друге, в цей час завершується формування першої 3 трьох релігійно-культурно-соціополітичних синтез, які виділяє в історії релігій Японії Дж.Кітагава синтези Рімурьо:, „парадигматичної форми іманентної теократії” [Kitagawa J. On Understanding Japanese Religion.- Princeton, New Jersey, 1987.- Р. XII-XVI]. Релігійно-філософська культура раннього Хейану складне, багатошарове явище. Ї̈ підгрунтя складали мовна концептуалізація світу класичною японською та, до певної міри, класичною китайською мовою, а також міфологічні уявлення, успадковані здебільшого від архаїчних часів. На цьому грунті розвивалися ідеї, пересаджені 3 континенту в попередній період конфуціанські, буддистські, даоські, що встигли добре прижитися тут за триста років (з VI по VIII ст.).

Розглянемо побіжно основні складові ранньо-хейанської релігійно-філософської культури. Почати доцільно з буддизму - вчення, яке зазвичай вважають за панівне в цей період. Щоб зрозуміти специфіку його становища в ранньому Хейані, згадаймо подію, яка позначила кінець доби Нара (710-793) - невдалу спробу ченця До:кьо: захопити трон [Детальніше про неї див.: Рубель В.А. Японська цивілізація: традиційне суспільство і державність.- К., 1997.- С. 74-77]. Дослідники вважають, що

* КАПРАНОВ С.В. - науковий співробітник Інституту сходознавства імені А.Кримського НАН України. 
це була одна з головних причин переносу столиці, адже в м. Нара був надто відчутний вплив буддистських монастирів. У новій столиці було заплановано лише два буддистські храми, до того ж храмам із Нари було заборонено переїздити до Хейана [История Японии.- Т.І.: С древнейших времен до 1868 г.- М., 1998.- С. 175-177]. Було вжито систематичних заходів з метою посилення контролю над буддистським духовенством [Буддизм в Японии.- М., 1993.- С. 85-87]; „при дворі взагалі посилилися антибуддистські (а разом 3 тим - й антиіноземні) настрої” [История Японии.- С. 151]. Відтак зміцнилися позиції сінто.

Як показали дослідження О. М. Мещерякова, у VI - VIII ст. в Японії ще не сформувалася буддистська традиція, становище буддизму порівняно 3 сінто було нестабільним. Статистичний аналіз джерел підтверджує охолодження у ставленні влади до буддизму в 70-ті pp. VIII ст. [Мещеряков А.Н. Древняя Япония: буддизм и синтоизм (проблемы синкретизма).- М., 1987.- С. 155-158].

Проте буддизм незабаром знову став впливовим вченням; більше того -саме в цей період відбувся перший розквіт японської буддистської філософії. I почався він з двох геніїв, Ку:кая (774-735) та Сайцьо: (767822). Вони принесли до Японії новий тип буддизму - так званий езотеричний буддизм (япон. міккьо: - дослівно „таємне вчення”). Саме він став культурною домінантою раннього Хейану. I це значною мірою завдяки титанічній особистості Ку:кая, чия діяльність охоплювала майже всі основні галузі тогочасної японської культури. Безпосередньо під впливом езотеричного буддизму розвинулося мистецтво цієї доби, насамперед храмова скульптура та іконопис. Розквіт буддистської дерев'яної скульптури припав на другу половину правління імператора Сейва - роки під гаслом Дзьо:ган (859-877). У японському мистецтвознавстві термін „Дзьо:тан” використовують для позначення раннього Хейану загалом [Matsumura Akira. Daijirin.- Tōkyō, 1989.- C. 1170; История культуры Японии. Обзор / Ю.Тадзава, С.Мацубара и др.Токио, 1992.- С. 43].

Езотеричний (тантричний) буддизм ставить на меті реалізацію природи Будди, тобто досягнення просвітлення, вже в актуальному житті, в актуальному тілі (сокусін дзьо:буцу), для досягнення чого використовують складний комплекс йогічних методів - „таїнств”, що поділяються на три класи: таїнства тіла (мудри), мовлення (мантри), свідомості (медитація). В цьому - одна 3 головних відмінностей тантричного буддизму від школи дзен, у якій просвітлення (camopi) досягають за допомогою лише медитації.

У власному сенсі слова „таємне вчення” в Японії - це школа сінгон, заснована Ку:каєм. Саме вона репрезентує „чисті таїнства” 
(дзьо:міщу), тоді як іiі головний опонент у добу Хейан - школа тендай, заснована Сайцьо:, у своєму езотеричному аспекті (тайміиу) належить до „змішаних таїнств” (дзо:міиу) [Трубникова Н.Н. „Различение учений” в японском буддизме IX в. Кукай о различиях между тайным и явным учениями.- М., 2000.- С. 8]. Езотеричний буддизм школи сінгон спирається на дві головні сутри - „Сутра Вайрочани” (японською „Дайніиі-кьо:”) та „Сутра Діамантової Вершини” (японською „Контоцьо:-кьо:”). У вченні сінгону тут варто виділити декілька моментів. По-перше, це підкреслення особливої ролі „таїнств мови” у загальному йогічному комплексі, що виразилося вже в самій назві школи - „сінтон”, що означає „правдиві (справжні) слова” або „правдиве мовлення” і $\epsilon$ перекладом санскритського терміну „мантра”. По-друге, це своєрідний „пантеїзм” (чи радше - „панбуддизм”) - уявлення про те, що весь феноменальний світ являє собою єдине тіло будди Вайрочани. По-третє, це своєрідна метафізика статі: Будда Вайрочана постає в неподільній єдності його двох аспектів - істинного світу (чоловічому аспекті) та присутності у феноменальному світі (жіночому аспекті). Ці три моменти знаходили аналогії в інших тогочасних вченнях: сінто з його уявленням про магічну душу слова - котодаму, пантеїзмом та культом сексуальності як прояву творчої сили; та оммьо:до: (див. нижче) 3 його діалектикою інь-ян, витлумаченою в сексуальному плані.

Ку:кай написав понад 50 праць, насамперед - релігійнофілософського змісту. Головні з них: капітальна праця „Хіміщу мандара дзю:дзю:сінрон” („Десять осель серця таємної мандали”), трактати „Бенкеммічу нікьо:-рон” (,Трактат про два вчення, явне й таємне, та про відмінності між ними”), „Сокусін дзьо:буцу-ті” („Про значення слів „стати Буддою в цьому тілі”), „Хідзо: хо:яку” („Коштовний ключ до таємного сховища") тощо. Крім того, серед творів Ку:кая - перший в Японії словник „Тенрей бансьо: мьо:гі”, лінгвістичні праці, зокрема - 3 санскриту, літературознавчі праці, вірші тощо. [Див.: Кукай. Избранные труды / Сост., подгот. текста и примеч., очерк по истории эзотерического буддизма А.Г. Фесюн.- М., 1999.- 244 с.; Трубникова Н.Н. Вказ. праця.368 c.].

Сайцьо: переніс до Японії і розробив на новому грунті вчення китайської школи тяньтай. В його основі - концепція Сдиної Колісниці (Екаяни). Школа тяньтай (японською - тендай) спирається на „Лотосову сутру”. До головних теоретичних здобутків Сайцьо: належить остаточна магаянізація японського буддизму, досягнута в полеміці з представником школи хоссо: (йогачара) - ченцем Токуїці, а також розробка концепції буддистської держави, в осередді якої - ідеал ченця-бодгісатви. Головні праці Сайцьо: „Хокке сю:ку” („Короткі рядки Лотосової Сутри”), „Кенкай 
рон” („Міркування щодо прояснення заповідей”), „Сюто коккай сьо:” (,Трактат про захист держави”) тощо [Детальніше див.: Буддизм в Японии. Вказ. праця.- С. 87-132].

Важливу роль у розвитку хейанського буддизму в Японії відіграло протистояння шкіл сінгон і тендай. Остання мала яскраво виражені владні амбіції, виражені, зокрема, у політичній доктрині іiі засновника Сайцьо:. Якщо в першій половині раннього Хейану (до 850-х pp.) більший вплив мала школа сінгон, то в другій половині, завдяки активній діяльності ії патріархів Енніна (794-864) та Енціна (814-891), посилилася школа тендай. Ім'я останнього 3 патріархів інколи транслітерують як Енсю. Еннін, учень Сайцьо:, розробив тейндайський езотеризм - тайміиу, фактично інкорпорувавши сінгонські доктрини до тендайського вчення. Він прирівняв один 3 двох головних канонічних текстів школи сінгон - „Сутру Вайрочани” (,Дайніці-кьо:”) до „Лотосової сутри”. Енцін пішов ще далі, поставивши „Сутру Вайрочани” над „Лотосовою сутрою”. Таким чином, перемогу школи тендай було здобуто ціною езотеризації, фактично - зближення зі вченням сінгону. 3 іменем Енніна пов'язане й запровадження практики нембуиу (декламації імені Будди), яке пізніше розвинулося в одній з провідних течій японського буддизму - амідаїзмі. Енцін розробив вчення про хонтаку - „первинну (фундаментальну) просвітлість”, що мало велике значення в подальшому розвитку буддистської думки в Японії.

Загалом можна зазначити, що для буддистської думки раннього Хейану характерні такі риси, як екуменізм (прагнення об'єднати всі напрями буддизму в єдину систему), універсалізм (в сенсі доступності спасіння для всіх) та езотеризм.

Паралельно з буддизмом існувала й автохтонна японська релігія сінто. Вище було сказано, що доба Хейан почалася з різкого „відкату” від буддизму до сінто. Вже в часи влади До:кьо: опозиція спиралася на ідеї рідної віри: його головний опонент, сінтоський священик Вакі Кійомаро від імені Бога Хацімана заявив: „Престол Сонця Небесного повинен успадковуватися імператорським домом. Неправедного ж потрібно вигнати" [Рубель В.А. Вказ. праця.- С. 76]. Як стверджує С.СимоноваГудзенко, „панівна еліта Японії усвідомила, що найкращим гарантом іiі спадкових привілеїв був сінтоїзм з його розвиненим культом предків, 3 якого випливало підкреслено шанобливе ставлення до історії та традиції взагалі” [История Японии. Вказ. праця.- С. 151].

Сінто віддавна було пов'язане $з$ державою. У VIII ст. цей зв’язок було оформлено юридично (кодексом „Тайхо: ріиурьо:” 701 р.): справи сінто було доручено Дзінгікану (Синоду), підпорядкованому безпосередньо імператору. Держава фінансувала сінтоські храми через 
систему спеціальних податків. Особливе місце було відведено храмам Iсе: при них існувала посада „священної цариці” - сайо:, зі своєю „столицею” - Таке-но Міяко та цілим двором. На посаду сайо: обирали незаміжніх принцес імператорського роду. У ранньому Хейані інститут сайо: переживав розквіт; аналогічні посади було створено також при столичних храмах Камо (801р.) та храмі Касуга, де шанували каміпредків клану Фудзівара [Детальніше див.: Капранов С.В. Жриці сайо в добу Хейан та „Ісе моногатарі” // Магістеріум. Випуск п'ятий. Культурологія.- К., 2000.- С. 29-40].

Сінтоські пам'ятки раннього Хейану - це збірка міфів Імібе Хіронарі „Кого сю:i” (807 р.) та генеалогічні списки „Сінсен съо:дзіроку” (,Знову укладений реєстр родів”, 815 р.). Наприкінці раннього Хейану було укладено „Енгісікі” („Ритуали років Енгі”), що містять багато давнього матеріалу, зокрема - молитви (норіто). Усе це свідчить про інтелектуальну активність послідовників сінто в цю добу. Відомо, що укладання „Сінсен сьо:дзіроку” було відповіддю на текст „Вакан сорекітей "фудзу” (транскрипцію назви подаємо за працею О.Мещерякова), створенний аристократами 3 іммігрантських родів, де було висунуто ідею рівності еліт різних країн на підставі спільного походження від верховного Божества - Аме-но Мінаканусі [Мещеряков А.Н. Вказ праця.- С. 52]. Отже, власне сінтоська думка в цей період працювала в руслі систематизації й кодифікації більш раннього матеріалу та генеалогічного обгрунтування соціального статусу еліти.

Але особливим досягненням цього періоду вважають розвиток сінто-буддистського синкретизму, зокрема розробку його теоретичної платформи - теорії хондзі-суйдзяку [Буддизм в Японии.- М., 1993.- С. 187-189; Накорчевский А.А. Синто.- СПб., 2000.- С. 320-327]. Тому сінто доби Хейан найкраще розглядати у його взаємодії з буддизмом.

У попередню добу (VII - 60-ті pp. VIII ст.) вплив буддизму зростав. Синто-буддистський синкретизм розвивався за моделями „навернення камі до буддизму” та „камі - охоронці буддизму”: при сінтоських храмах будували особливі буддистські каплички - дзінгу:дзі (3 698 р.), буддистські ченці читали сутри для камі (сіндзен докьо:). Як твердить Ямаорі Тецуо, ченець при дзінгу:дзі вважався вищим за сінтоського священника-каннусі відповідного храму [Yamaori Tetsuo. Jingūji // Encyclopedia Nipponica 2001. Nihon daihyakka zensho. - Tōkyō, 1984-1994.- Dai 12 kan.- P. 490]. Проте поступове підвищення статусу сінто призвело до перемоги іншої моделі взаємодії - теорії єдиносущності будд і камі хондзі-суйдзяку. За цією теорією кожного камі розглядали як прояв (суйдзяку) певного будди або бодгісатви, що складає його сутність (хондзі). Таким чином, камі вже не потребував „навернення” до буддизму. 
Датування переходу від першої моделі до другої викликає дискусії, тому варто розглянути цей процес детальніше.

Теоретичною базою для доктрини хондзі-суйдзяку стали вчення Ку:кая та Сайцьо:. Перший висунув положення про проповідь Будди в „тілі закону рівного виливу”, імпліцітно присутню в небуддистських вченнях [Трубникова Н.Н. Вказ. праця.- С. 35-39]; другий поширив у Японії теорію Чжії про поділ Лотосової Сутри на дві частини - вступні проповіді (сякумон, дослівно - „брама сліду”) та основні проповіді (хоммон, „основна брама”) [Карелова Л.Б. Синто-буддийский синкретизм XIII - XV вв. // Буддийская философия в средневековой Японии.- М., 1998.- С. 245]. Проте легенди про вшанування камі цими патріархами викликають серйозні сумніви дослідників [Буддизм в Японии.- Вказ. праця.- С. 188]. Прояви доктрини хондзі-суйдзяку знаходять у листі Ерьо: до імператора 859 р. [Ishida Ichirō. Shinto:-no shisō // Shintō shisōshū. Tōkyō, 1972.- Р. 13]. Вперше поняття суйдзяку щодо камі вжито в історичній хроніці „Сандайдзічуроку” („Правдиві записи трьох поколінь”, 901 р.) [Карелова Л.Б. Вказ. праця.- Там само], а в експліцитній формі ця ідея з'являється вже на початку зрілого Хейану - в наказі 937 р. [Буддизм в Японии. Вказ. праця.- Там само]. В XI-XII ст. вона набуває популярності, що засвідчено багатьма текстами [Ishida Ichirō. Op. cit., ibid]. Систематичні виклади теорії хондзі-суйдзяку з'являються лише в добу Камакура. Отже, щодо раннього Хейану можна з певністю казати лише про формування теоретичних передумов згаданої теорії. Панівними у взаємодії сінто з буддизмом лишалися моделі „навернення камі до буддизму” та „камі- захисники буддизму”.

Освіта аристократів у добу Хейан, як і в добу Нара, передбачала опанування „китайської науки” (кантаку) - тобто, насамперед, конфуціанства. Здебільшого історію цього напряму японської думки починають з Фудзівари Сейки (1561-1619), в крайньому разі - 3 дзенбуддистських ченців XIII-XIV ст. 3 іншого боку, відомо, що японці познайомилися з конфуціанством досить давно: навіть якщо традиційна дата (286 р.) й не відповідає дійсності, то, за найкритичнішими оцінками, в IV-V ст. ідеї Кун-цзи вже були відомі в Японії, а в VI ст. тут вже склалася власна конфуціанська традиція [Радуль-Затуловский Я.Б. Конфуцианство и его распространение в Японии.- М.-Л., 1947.- С. 195]. Їі вплив дуже помітний у „Конституції 17-ти статей” принца Сьо:току (604 р.). У період Нара сформувалася система освіти, що включала такі дисципліни, як мьо: ььо:до: - конфуціанська класика, кідендо: - історія Китаю до кінця династії Хань, мьо:бо:до: - юриспруденція, сандо: математика, сьо:до: - каліграфія, ондо: - філологія тощо (у згаданій вище праці Я.Б. Радуль-Затуловського назви дисциплін наведено з помилками 
- мейкейдо: замість мьо:Іьо:до: та мейхо:до: замість мьо:бо:до:; ми подаємо їх за тлумачним словником: [Matsumura Akira. Daijirin.- Tōkyō, 1989]). Хоча всі ці науки містили філософські ідеї, слід звернути особливу увагу на мьо:тьо:до: (дослівно - „шлях висвітлення канонів”) та кідендо: („шлях хронік і літописів”). Перша 3 цих дисциплін передбачала вивчення дев'яти класичних текстів: трьох канонів (Ші-цзін - „Канон священних гімнів”, Шу-цзін - „Канон історії, І-цзін - „Канон змін”), трьох книг про ритуал/етикет (Чжоу лі - "Чжоуський етикет", I лі "Взірці ритуалу та етикету", Лі цзі - "Записи про етикет") та літопису Чунь цю („Весни й осені”) $з$ трьома коментарями (Цзо чжуань, Гун'ян чжуань та Гулян чжуань). Це - практично повний корпус традиції, на яку спирався Конфуцій. Кідендо: - це вивчення „Історичних записів” Сима Цяня, „Історії династії Хань”, укладеної Бань Гу, та „Історії Пізньої Хань” Фань Є [Радуль-Затуловский Я. Б. Вказ. праця.- С. 204-205]. Крім інформації про історичні події, ці тексти містять багатий філософський матеріал: історіософські думки, біографії мислителів, історію та класифікацію філософських шкіл, бібліографію філософських праць, навіть цілі трактати - як-от „Три доповіді про Небо й Людину” засновника конфуціанської ортодоксії Дун Чжуншу [Див.: Китайская философия: Энциклопедический словарь.- М., 1994.- С. 369-370, 373, 499500]. До того ж, японські конфуціанці добре знали Лунь юй („Бесіди та судження” Конфуція) та Сяо цзін („Канон пошани до батьків”). Якщо в період Нара викладачами згаданих предметів були переважно іноземці китайці та корейці, то 3 початку періоду Хейан „китайська наука” перейшла до рук японців. Поступово склалися клани, що спадково спеціалізувалися з певних дисциплін: родини Сугавара та О:е займалися кідендо:, Кійовара та Накамото - мьо:тьо:до: [Радуль-Затуловский Я. Б. Вказ. праця.- С. 204-205]. Відбулися й інші зміни, зокрема - посилилася роль кідендо: [Heian-kyō.- Tōkyō, 1967.- P. 169-171].

Конфуціанська думка раннього Хейану відбилася насамперед у хроніках. Вартий уваги той факт, що з шести офіційних хронік (ріккокусі) п’ять (!) написано саме в цей період: „Сьоку Ніхонті” („Продовження анналів Японії, 797 р.), „Ніхон ко:кі” („Пізніша хроніка Японіі”, 841 р.), „Сьоку Ніхон ко:кі” („Продовження пізнішої хроніки Японіи”, 869 р.), „Монтоку тенно: дзіиуроку” („Правдиві записи про часи імператора Монтоку”, 871-878 рр.) та „Сандай дзічуроку” („Правдиві записи трьох поколінь", 901 р.). В укладанні останньої брав участь видатний конфуціанець Сугавара-но Міцідзане. Він також написав працю з історії Японії - „Рідзю:кокусі” („Систематична історія держави”, 892 р.) [Melanowicz M. Literatura Japońska.- Warszawa, 1994.- T. I.- S. 124]. 
Іншим видатним конфуціанцем кінця раннього Хейану був Мійосі-но Кійоцура (або Кійоюкі, 847-918) - один 3 „винятково критичних розумів доби”, за характеристикою М.Меляновича [Melanowicz M. Op. cit. - T.I. - S.120-121]. Йому належить „Меморандум у 12 статтях" („Ікен фу:дзі дзю:нікадзьо:”; 914 р.), який містить антибуддистські заклики [Нагата Хироси. История философской мысли Японии.- М., 1991.- С. 59]. У часи раннього Хейану з'являється ще один жанр конфуціанських текстів - розгорнуті коментарі до кодексу законів „Йоро: рьо:”: „Рьо:-но тіте” (833 р.) Кійохара-но Нацуно, та „Рьо:-но сю:те" (859-877 рр.) Коремуне-но Наомото. Такі коментарі містили й чимало загальних ідей щодо права, суспільства, етики, держави тощо.

На жаль, конфуціанство раннього Хейану мало досліджене, оскільки його представники, на відміну від своїх наступників, не писали філософських трактатів, а викладали свої думки в історичних та юридичних текстах, а також у „китайських” віршах - кансі. Детальніше вивчення цієї сторінки японської думки має стати одним із завдань дослідження історії японської філософії з позицій культурологічного підходу.

Крім конфуціанства, до складу „китайської науки” входив даосизм. Його поява в Японії також відбулася в ранні часи, хоча важко сказати, коли саме. Принаймні в VI-VII ст. японці вже були знайомі з цим вченням. Стислий виклад сучасних поглядів на час і спосіб появи даосизму в Японії добре розглянуто в праці „Nihon shūkyō jiten” [Див: Nihon shūkyō jiten / Ono Y., Shimode S. et al.- Tōkyō, 1994.- P. 419-424]. Якщо конфуціанство відігравало у тогочасній Східній Азії роль методології суспільних наук (етики, політології, юриспруденції, історії тощо), а також математики, то даосизм складав методологію наук природничих (медицина, астрономія тощо), тісно пов'язаних 3 магією, астрологією, алхімією. Вже в період Нара всі ці дисципліни, а також вірування народного даосизму, зокрема - віра в сянів, святих безсмертних - міцно вкоренилися в японський грунт. Зокрема, діяла Академія медицини з розгалуженою спеціалізацією [Garnuszewski Z. Akupunktura w kraju Samurajów: wczoraj i dziś.- Warszawa, 1994.- S. 8].

У період, що нас цікавить, відбувається помітний зріст цікавості до всіх відмін даосизму. Імператор Камму (роки правління 781-806), що побудував нову столицю - Хейан, захоплювався даосизмом і двічі влаштовував свято на честь Хао-Тянь Шанді (даоського Бога Великого Неба). Пізніше це свято провів ще раз імператор Монтоку (роки правління 850-858) [Fujimaki Kazuyasu. Ommyōdō to yami-no Nihonshi (kodaihen) // Ommyōdō-no hon.- Tōkyō, 1999.- P. 55]. Починається поглиблене вивчення класиків даоської філософії - Лао-цзи та Чжуан- 
цзи. Імператор Німмьо: (роки правління 833-850), відомий своїм інтересом до даоських практик, слухав лекції Харудзумі-но Йосітади 3 філософії Чжуан-цзи; імператор Дайго (роки правління 897-930) студіював Лао-цзи під керівництвом О:е-но Коретокі.

Укладений наприкінці IX ст. Фудзівара-но Сукейо бібліографічний довідник „Ніхон коку кендзай сьомокуроку” згадує кілька коментованих текстів „Дао де цзіну”, „Лао-изи хуа ху цзін” (,Канон [про те, як] Лао-цзи просвіщав варварів") Ван Фу (кінець III ст.), канон даоської алхімії „Баопу-цзи” Ге Хуна (283 - 343/363) й низку інших даоських книг, в тому числі й медичних [Nihon shūkyō jiten. Op. cit.- P. 424, 426]. У ранній період Хейан з'являється й перша японська медична праця - „Дайдо: руйсю:хо:" (808 р., не збереглася). Про тогочасну японську медичну думку ми можемо певною мірою судити за енциклопедією „Ісімпо:” Тамбо-но Ясуйорі (984р.) [Garnuszewski Z. Op. cit.- S. 11-12; Nihon shūkyō jiten. Op. cit.- P. 439].

3 даосизмом тісно пов'язаний комплекс ідей та практик, відомий як оммьо:до: або онйо:до: - „шлях інь-ян”. Ця назва відсилає до однієї зі шкіл класичної китайської філософії за класифікацією Сима Цяня - iнь-ян цзя, „школа інь-ян” (у європейській науці іiі часто називають натурфілософською). Головний представник цієї школи, Цзоу Янь (IV-III ст. до н.е.) об'єднав діалектику інь-ян зі вченням про „П’ять елементів” (точніше, фаз або рушіїв). У Китаї, проте, інь-ян цзя влилася до конфуціанства (у своєму філософському аспекті) та даосизму (в аспекті релігійно-окультному), припинивши, відтак самостійне існування ще на початку доби Хань (202 р. до н.е. - 220 р. н.е.) [Китайская философия. Вказ. праця.- С. 138-139]. Таким чином, коли японці познайомилися 3 „китайською наукою”, вчення про інь-ян та п'ять рушіїв було спільною мовою і конфуціанства, і даосизму, але термін „шлях інь-ян” закріпився в Японії саме за релігійно-окультною (за виразом А. І. Кобзєва) відміною вчення.

У власному значенні слова оммьо:до: сформувалося саме на японському грунті. Фудзімакі Кадзуясу вирізняє такі головні джерела „шляху інь-ян”: китайське вчення про інь-ян та п'ять рушіїв, популярний даосизм (мінкан до:кьо:, на відміну від інституціоналізованого даосизму - сейріиу до:кьо), початкове сінто та „різні містерії (дзаиуміиу). Він, посилаючись на Мураяму Сю:іці, поділяє ранню історію оммьо:до: на чотири періоди: (1) від стародавніх часів до імператора Кейтая (правив 507-531); (2) від правління Кейтая до кінця доби Нара (кінець VIII ст.); (3) від імператора Камму (правив 781 - 806), що розпочав добу Хейан, до X ст.; (4) з X ст. до початку доби Камакура [Fujimaki Kazuyasu. Op. cit.- P. 38-39]. У перший період закладаються передумови виникнення 
майбутнього вчення - розвиваються місцеві вірування, шаманізм i водночас відбувається поступове проникнення до Японії знань 3 материка. За імператора Кейтая японці вперше познайомилися зі вченням про інь-ян та п’ять рушіїв, принесеним з Кореї (Пекче) Тан Ян'ї та Ханго Анму - „докторами П'яти канонів” (до числа яких входили найважливіші тексти вчення - I цзін та „Великий план”, одна 3 глав Шу цзіна); за імператриці Суйко (правила 592-628) чернець з Пекче Квангин приніс до Японії китайську езотерику (астрологію, магію тощо) [Нихон сёки Анналы Японии: В 2-х т. / Пер. и коммент. Л.М. Ермаковой и А.Н. Мещерякова.- СПб., 1997.- Т.2.- С. 13, 16, 93]. Зазначимо, що першооснови оммьо:до: було закладено конфуціанцями та буддистськими ченцями. За імператора Темму (роки правління 673-686), „технократа оммьо:до:”, за висловом Фудзімакі, шлях інь-ян було поставлено на службу державі. Для цього було створено особливу інституцію - „Палату інь-ян” (Оммьо:рьо:). Відбулася бюрократизація оммьо:до:

Третій період розвитку оммьо:до: припадає саме на ранній Хейан i початок зрілого Хейану. У цей період відбувалася, по-перше, „приватизація” оммьо:до: (звільнення його від державного контролю та проникнення до приватного життя аристократіі), по-друге, „японізація” цього заморського вчення. Водночас посилився інтерес до китайського окультизму. Деякі оммьо:дзі - “майстри інь-ян” (наприклад, Харудзоно Таманарі) їздили до імперії Тан (618-907) вивчати "таємні науки”. То був час розквіту оммьо:до:, зростання його популярності. Нова столиця місто Хейан - була побудована за всіма правилами мистецтва фен-шуй, яке входило до компетенції оммьо:дзі. Астрологія, фен-шуй, ворожба на І-цзіні стали невід'ємною частиною життя хейанських аристократів. Про таких майстрів інь-ян цієї доби, як Сігеока-но Кавахіто та Юrе-но Корео, ходили легенди, зафіксовані в пізнішій літературі - "Кондзяку моногатарі", "Удзісю:ї-моногатарі" тощо. Деякі 3 них (наприклад, вищезгаданий Сігеока-но Кавахіто) писали трактати [Fujimaki Kazuyasu. Op. cit.- Р. 52-58]. Ранній Хейан, таким чином, підготував грунт для появи в Х ст. видатних оммьо:дзі - Камо-но Тадаюкі, Камо-но Ясунорі, Абе-но Сеймея.

Особливе місце у філософській культурі раннього Хейану посідає поетика, яскравим взірцем якої є передмова Кі-но Цураюкі до поетичної антології “Кокінсю:” [Ки-но Цураюки. Предисловие к „Кокинсю” // Восточная поэтика: Тексты. Исследования. Комментарии.- М., 1996.- С. 63-85].

3 усього сказаного вище можна зробити такі висновки. Поле релігійно-філософської культури раннього Хейану формували чотири 
головні вчення (буддизм, сінто, конфуціанство й даосизм) та силові лінії взаємного тяжіння й протистояння між ними. При цьому буддизм і сінто протистояли „китайським наукам” - конфуціанству й даосизму як релігійні - нерелігійним. Саме тому буддизм і сінто відігравали провідну роль у синтезі Ріцурьо:, формування якої завершувалося в цей час. Сінто протистояло всім іншим вченням як „питомо японське” - „чужим”. Динаміка процесів, викликана, 3 одного боку, посиленням сінто й нестабільним на початку доби становищем буддизму, а з іншого боку переходом японської семіосфери від рецепції чужих до продукування власних текстів, полягала в японізації (тобто „сінтоїзації”) інших вчень, знятті напруги між ними шляхом утворення синкретичних вчень тощо.

Х.Хоффманн ${ }^{*}$ (Польща)

\section{ТАДЕУШ ЗЕЛІНСЬКИЙ I РІХАРД ГАНСИНЕЦЬ ЯК ДОСЛІДНИКИ АНТИЧНИХ РЕЛІГІЙ}

Польські наукові релігієзнавчі дослідження мають свій початок, як і в багатьох європейських країнах, у другій половині дев'ятнадцятого сторіччя. Поставали вони тоді в дусі позитивізму й еволюціонізму. Їхній генезис, так само, як і західноєвропейських, був пов'язаний із відходом від властивих романтизму міфологічно-порівняльних методів досліджень, званих Comparative Mythology, і поверненням до вивчення релігії у всіляких іiі проявах і аспектах [Див.: Nowaczyk M. Zarys dziejów religioznawstwa w Polsce. Przewodnik bibliograficzny.- Warszawa 1962; Szolc P. O. /Scholz/ Religionswissenschaft in Polen // Numen-Leiden, 1971.T. XVIII.- Z. 1.- S. 45-79; Poniatowski Z. The Beginnings of the Science of Religions in Poland (1873-1918) // Studia Religioznawcze.- Warszawa, 1979.N 14.- S. 11-51; Grzymała-Moszczyńska H., Hoffmann H. The Science of Religion in Poland: Past and Present // Method \& Theory in the Study of Religion.- Leiden, 1998.- S. 352-372].

Характерною рисою польських релігієзнавчих досліджень у процесі їхнього формування був той факт, що вони поєднувалися 3 іншими видами науки. Випливало це як з теоретично-методологічних, так i організаційних й особистих передумов. У цей час польське релігієзнавство не мало статусу академічної науки, а тому виразниками

\footnotetext{
ХОФФМАНН Х. - доктор філософії, професор Інституту релігієзнавства Ягеллонського університету (Краків, Польща).
} 